\title{
Mineral composition features of kimberlites from the Upper Muna field (Yakutia)
}

\author{
D.A. Yakovlev, S.I. Kostrovitsky, N.V. Alymova \\ Institute of Geochemistry SB RAS, Favorskyi str. 1 a, Irkutsk, Russia
}

We have studied the composition of minerals from kimberlites, composing the Upper Muna (Verhknemunsk) field. Based on results from these studies we have revealed the features of kimberlites in comparison with other diamond-bearing fields of the Yakutian Province. The most typical kimberlites for the given field include porphyry monticellite and micaceous kimberlites, demonstrating massive texture and different serpentine alteration. Blocks of weakly altered kimberlite with significant olivine content are frequently found.

Kimberlites demonstrate an extremely nonuniform distribution of groundmass minerals, wide variations of their compositions and zoning found for the majority of minerals (fig. 1). A distinctive feature of groundmass is a wide occurrence of such minerals, as monticellite, perovskite, calcite having relatively high content of strontium $(0,5$ wt. $\% \mathrm{Sr})$, as well as occurrence of grossularite - andradite garnet (fig. 2). Features of groundmass mineral composition indicate high-temperature conditions of final stages in kimberlite origin of the Verhknemunsk field.

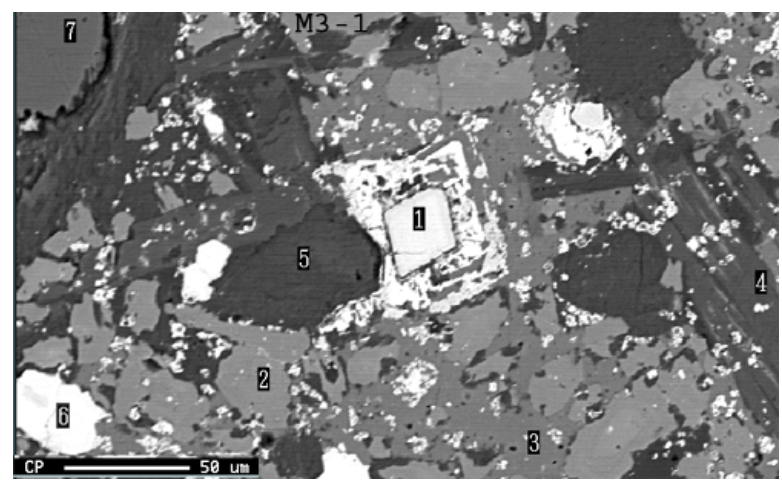

Fig. 1. Groundmass of kimberlite frome pipe Deimos (back-scattered electron image). 1 - idiomorphic spinel in Ti-magnetite atolls, 2 - monticellite, 3 - carbonate, 4 - chlorite, 5 - serpintine, 6 - perovskite, 7 - olivine.

Barophilic minerals in the heavy fraction from kimberlites of the Verhknemunsk field are characterized by the following features: 1) occurrence of two groups of garnet megacrysts in kimberlites of the studied pipes - chromium and titanium (Khar'kiv et al, 1998); 2) the heavy fraction of kimberlites contains a high share (about $7 \%$ ) of low-Cr low-Ca garnets belonging to dunite-harzburgite paragenesis (fig. 3); 3) spinels form two trends of crystallization: a) low-Ti, conditionally termed as "xenogenic" (Kostrovitsky, 1986) and b) with variable $\mathrm{TiO}_{2}$, termed as "kimberlitic" (fig. 4); 4) ilmenites from the Verhknemunsk field demonstrate individual pattern of composition trends as compared with ilmenites form other kimberlite fields of the Yakutian province (fig. 5).

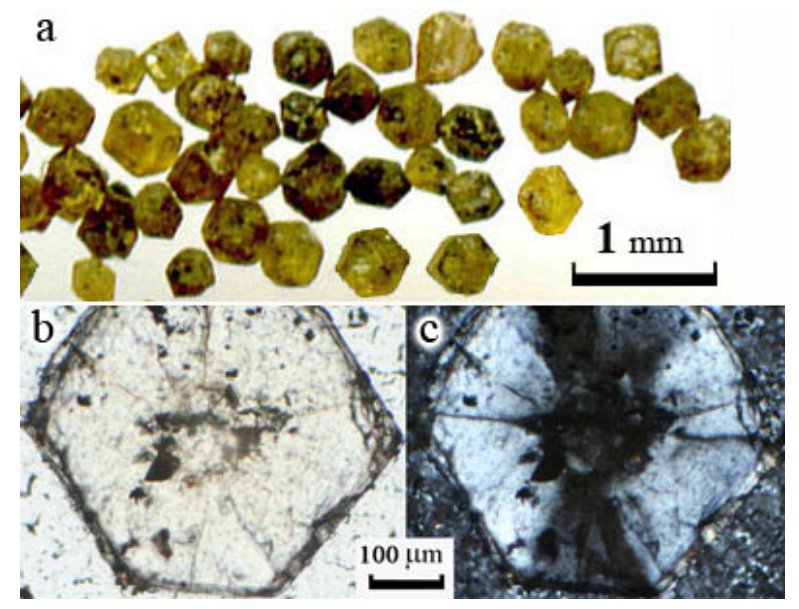

Fig. 2. Idiomorphic grossular (a) with magnetite inclusion $(\mathrm{b}-$ plane polarized, $\mathrm{c}-$ crossed polars).

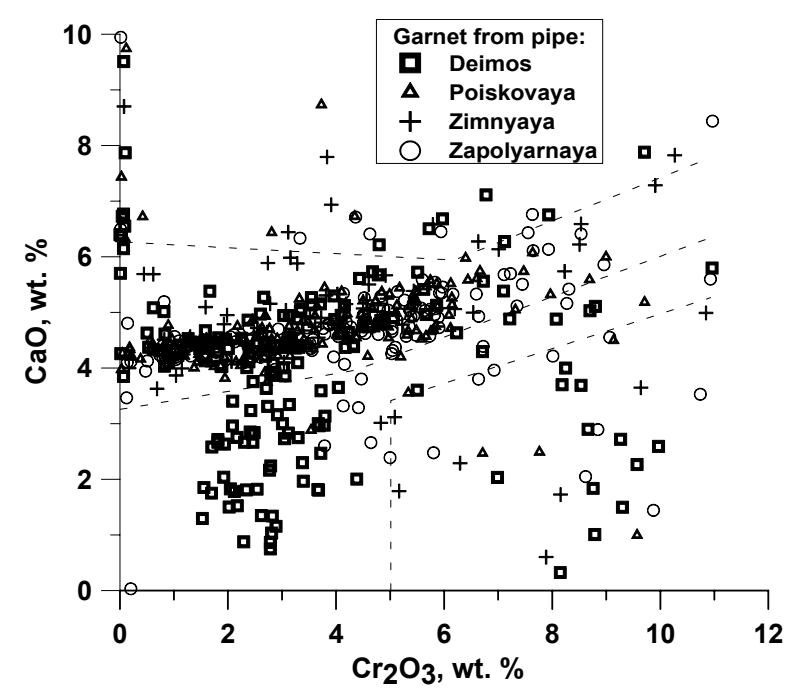

Fig. 3. $\mathrm{Cr}_{2} \mathrm{O}_{3}-\mathrm{CaO}$ relations for garnets from different pipes (293 analyses). Fields of garnet compositions fixed by parameters of lines, put by 
Sobolev (1974) for demarcation duniteharzburgitic, lerhzolitic and verlitic paragenesis.

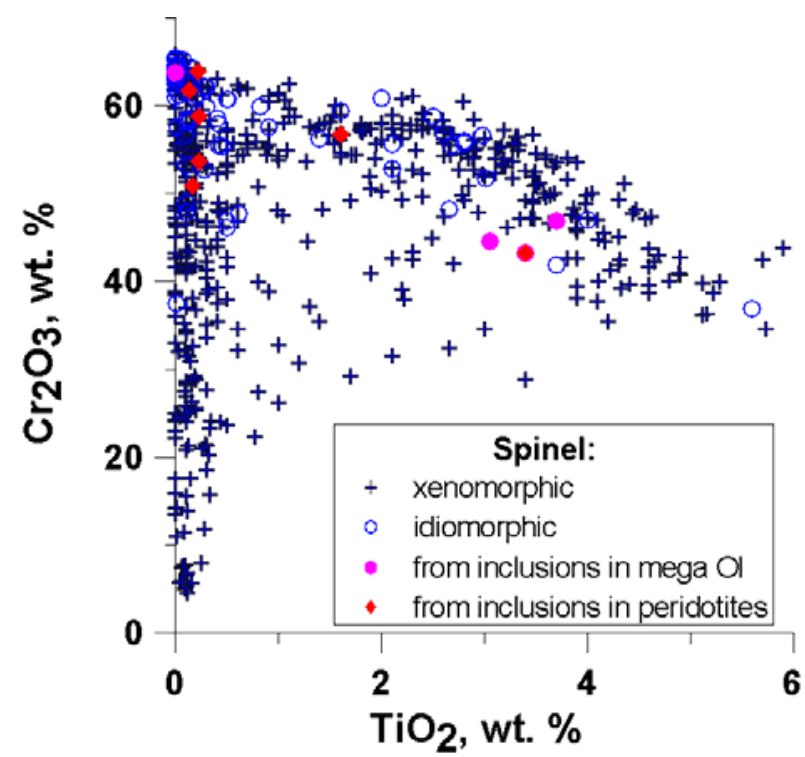

Fig. 4. $\mathrm{Cr}_{2} \mathrm{O}_{3}-\mathrm{TiO}_{2}$ relations for spinel.

Typomorphic characteristics of indicator minerals were used as a basis for the mineralogical classification of kimberlites of the Verhknemunsk field. As a results of these studies we have revealed both certain differences between pipes in terms of the composition of garnet, spinel and ilmenite and general features of the composition of these minerals typical of the field as a whole. Based on the obtained data concerning the composition of garnets from the heavy fraction of kimberlites as well as from deep-seated xenoliths we have arrived at the conclusion regarding a specific composition of the lithosphere mantle under the Verhknemunsk field as opposed to other diamondbearing fields.

The lithosphere mantle under the Verhknemunsk field mainly contains rocks of olivine composition, being dominated by the association of low-Cr garnets of dunite-hazrburgite paragenesis which are very rare for other diamond-bearing fields (fig. 6). A similar sinusoidal pattern of REE distribution in garnets of dunite-harzburgite paragenesis (fig. 7), irrespective of $\mathrm{Cr}_{2} \mathrm{O}_{3}$ content, indicates a common source responsible for their rare-element composition, which is probably, connected with cryptometasomatism. By thermodynamic parameters, which are $\mathrm{P}=45-75$ kbars and $\mathrm{T}=900-1400{ }^{\circ} \mathrm{C}$ (Nimis, Taylor, 2000), the crystallization of barophilic minerals from kimberlites and minerals of the mantle xenoliths from the Verhknemunsk field's pipes corresponds to diamond-pyrope facies, that agrees with ideas concerning the origin of melts in the astenosphere layer of the mantle (fig. 8).
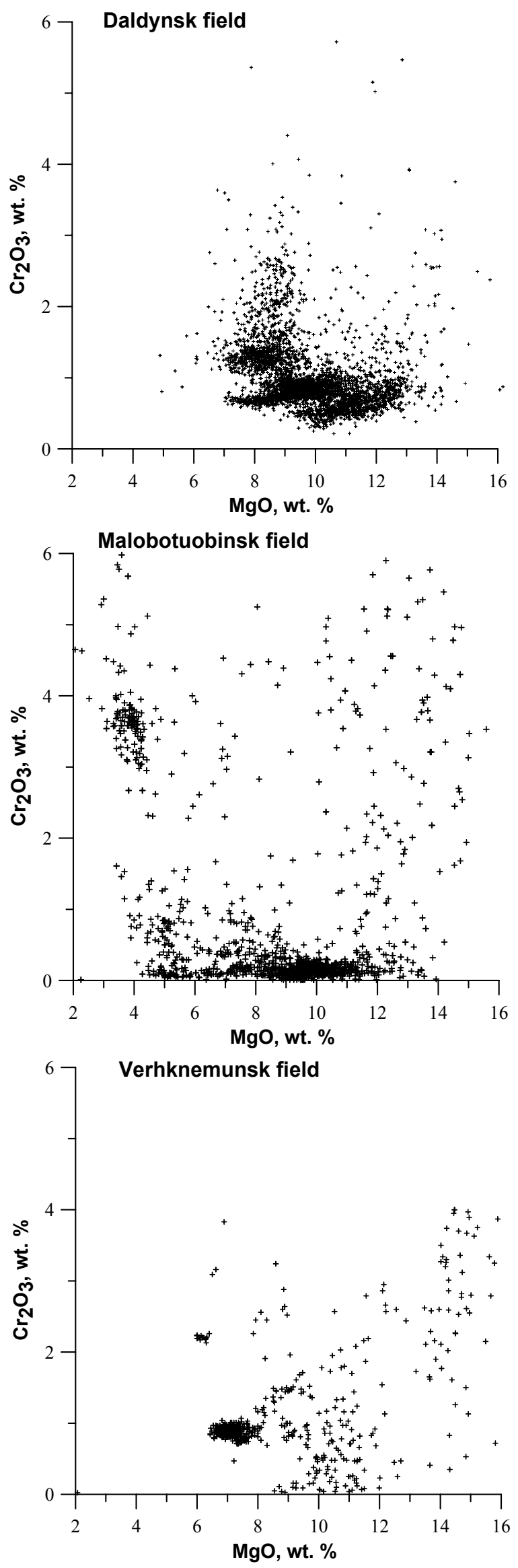

Fig. 5. $\mathrm{Cr}_{2} \mathrm{O}_{3}-\mathrm{MgO}$ relations for ilmenite from kimberlite of Daldynsk, Malobotuobinsk (Kostrovitsky et al, 2006) and Verhknemunsk fields. 


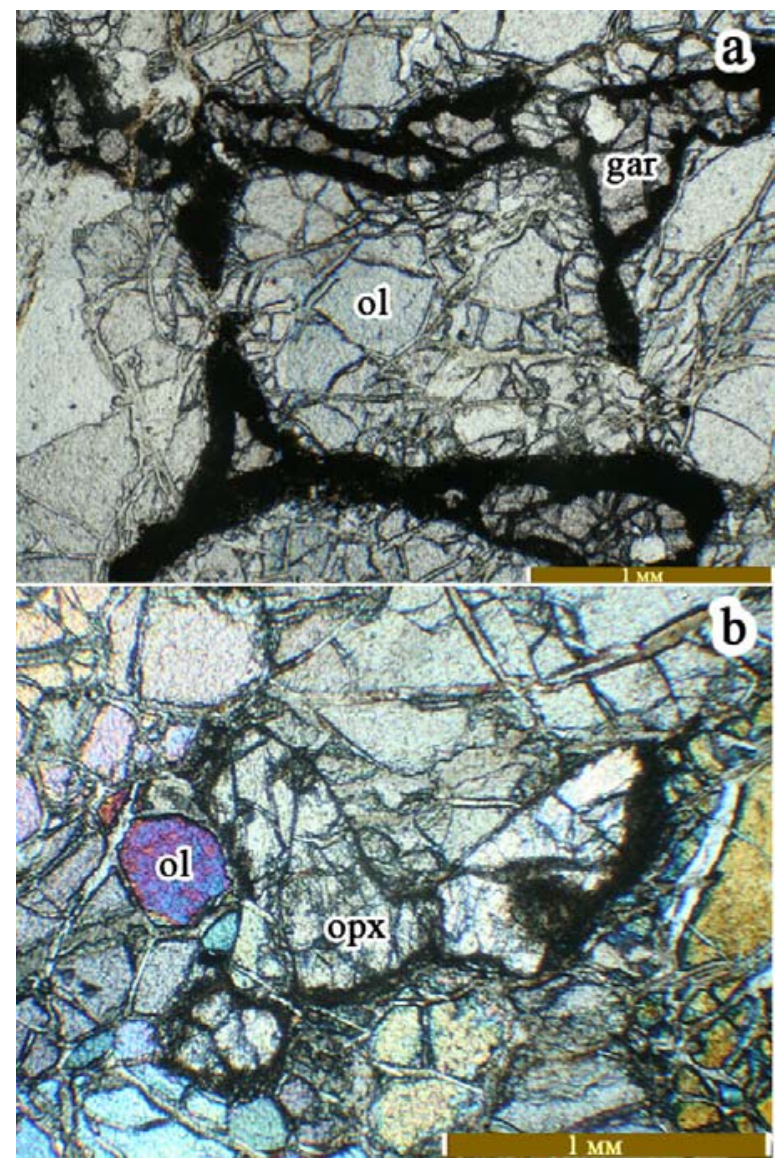

Fig. 7. Sp-Gar dunite-hazrburgite from pipe Komsomolsk-Magnitnaya a) Garnets with kelyphitic alteration rims. Plane polarized, lenth of ruler is $1 \mathrm{~mm}$. б) deformed orthopyroxene is surrounded by rim of brown amphibole. Crossed polars, lenth of ruler is 1 $\mathrm{mm}$.

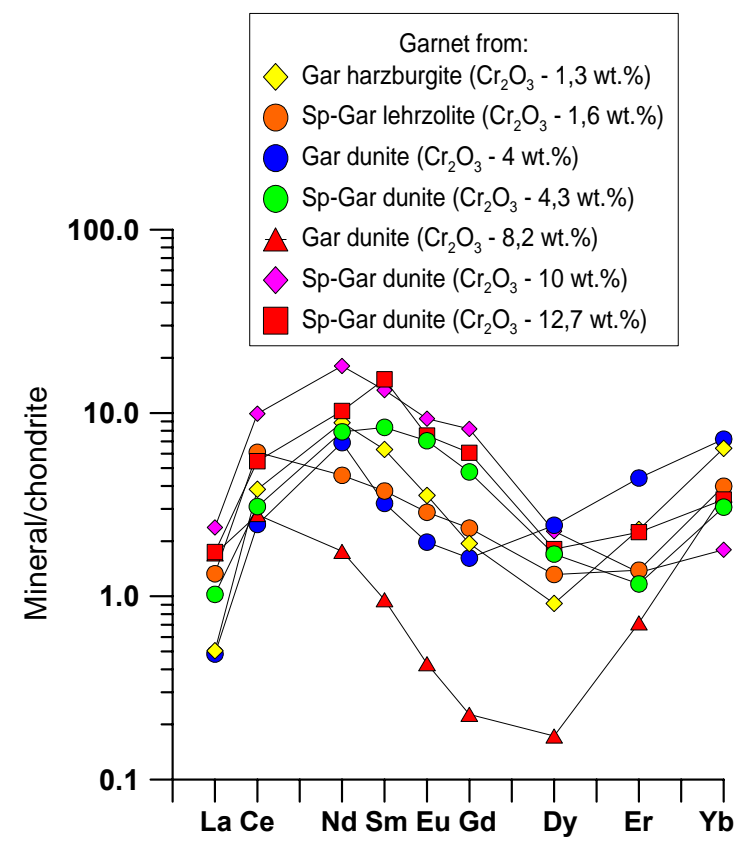

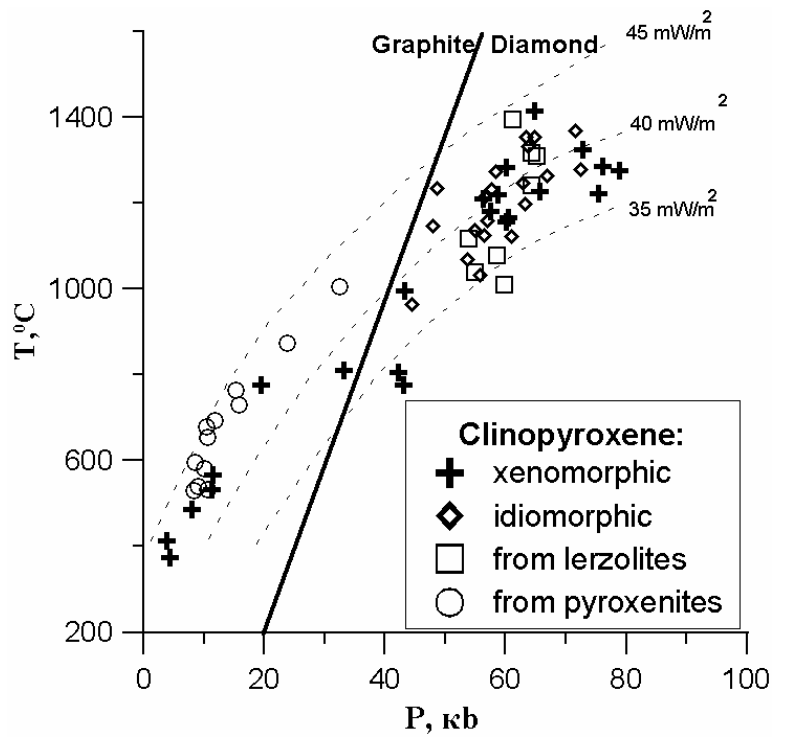

Fig. 8. P-T relations for clinopyroxene of Verhknemunsk field. The size of idiomorfphic and xenomorphic clinopyroxene is about $1 \mathrm{~mm}$.

\section{References}

Khar'kiv, A.D., Zinchuk, N.N., Kryuchkov, A.I., 1998. Primary deposits of diamond [in Russian]. Nedra, Moscow. 1998. 555 p.

Kostrovitsky, S.I., 1986. Geochemical features of minerals from kimberlites [in Russian]. Nauka, Novosibirsk. $263 \mathrm{p}$.

Kostrovitsky S.I., Alymova N.V., Yakovlev D.A., Serov I.V., Ivanov A.S., Serov V.P.

"The typochemism features of picroilmenite from different diamond-bearing fields of Yakutian province". [in Russian] Dokladi RAS. 2006.V 406. №3. P. 350-354.

Nimis P., Taylor W.R. (2000): Single clinopyroxene thermobrometry for garnet peridotites. Part 1. Calibration and testing of a Cr-in Cpx barometr and an enstitite-in-Cpx thermometr // Contrib. Mineral. Petrol., v. 139, N 5, p. 541-554.

Sobolev N.V., 1974. Deep-seated inclusions in kimberlites and the problem of the composition of the Upper Mantle (in Russian), Novosibirsk, Nauka, 263 pp. English Translation by Brown D.A, Boyd F.R., ed., 1977, AGU, Washington D.C., p. 279.

Fig. 7. REE distribution patterns for garnets from harzburgites and dinites. In brackets is given $\mathrm{Cr}_{2} \mathrm{O}_{3}$ content in garnets. 
